\title{
Pelatihan Pembukuan Keuangan Sederhana dalam Rangka Pelaksanaan Kebijakan Pajak yang Baru (PP Nomor: 23/2018) Untuk Pelaku UMKM Naik Kelas di Kota Depok
}

\author{
Notika Rahmi ${ }^{1}$, Chairil Anwar Pohan ${ }^{2}$, Pebriana Arimbhi ${ }^{3}$, M. Mansur ${ }^{4}$, Zulkifli ${ }^{5}$ \\ Institut Ilmu Sosial dan Manajemen STIAMI, Jakarta, Indonsia 1,2,3,4,5 \\ notika.rahmi@gmail.com ${ }^{1}$, anwar.phn@gmail.com ${ }^{2}$; pebrianasusanto@yahoo.co.id ${ }^{3}$ mansyur_mum@yahoo.com ${ }^{4}$ \\ zulkifli.nuh65@gmail.com ${ }^{5}$
}

\section{ARTICLE INFO}

Keywords

MSMEs

Accounting

PP No.23/2018
ABSTRACT
The existence of Micro, Small and Medium Enterprises (MSMEs) can no longer be doubted because they are proven to be able to survive and become the economic cogs. In 2011 MSMEs were able to contribute significantly to state revenue by contributing 61,9 percent of gross domestic product (GDP) revenue through tax payments. But the development of MSMEs in Indonesia is still very weak, one of the problems faced is human resources. MSMEs require targeted empowerment, guidance and development to be able to compete with large-scale companies. From the tax sector, the government has made special rules to facilitate MSMEs business people in their tax payments, namely through PP Number 23 of 2018. And furthermore it is expected that MSMEs business players can increase the level of making simple accounting which will help to tidy the administration of their businesses. In this case, we help MSMEs businesses to improve their capability and understanding in accounting and the new Tax Regulation (PP no.23/2018). This activity was attended by 51 MSMEs business people in the city of Depok. After attending the training, participants were given the opportunity to ask questions and consult. The results of the training and mentoring show an increase in knowledge about simple accounting that can be made by the participants themselves and participants become aware of the new taxation rules namely PP No.23 of 2018 as well as raising awareness about the importance of paying taxes.

\section{A. PENDAHULUAN}

Menteri Keuangan menerangkan bahwa kontribusi penerimaan pajak pada 2018 dari sektor UMKM berada dikisaran Rp5,7 triliun atau masih sangat minim apabila dibandingkan dengan total penerimaan perpajakan nasional yang mencapai sebesar Rp1.500 triliun, padahal hingga saat ini, UMKM memegang porsi hingga 65 persen dari sisi jumlah pelaku usaha dalam perekonomian di Indonesia, tapi dari sisi jumlah pembayar pajak yang aktif, baru mencapai 1,8 juta UMKM (Bisnis.com, 2019). Pajak sebagai salah satu sumber penerimaan bagi Negara mempunyai arti dan fungsi yang sangat penting untuk proses pembangunan. Pajak selain berfungsi sebagai budgetair, yaitu suatu fungsi dimana pajak dipergunakan sebagai alat untuk memasukan dana secara optimal ke kas negara berdasarkan undang-undang yang berlaku. Fungsi ini disebut sebagai fungsi utama karena fungsi inilah yang secara historis pertama kali timbul, berdasarkan fungsi ini pemerintah memungut dana dari penduduknya untuk membiayai berbagai kepentingan negara. Selain itu pajak juga berfungsi sebagai regulerend yakni sebagai fungsi tambahan/pelengkap dari fungsi yang utama, untuk mencapai tujuan tersebut maka pajak digunakan sebagai alat kebijaksanaan pemerintah (Pohan, 2017, hal. $35 \& 38)$.

Direktur Jenderal Pajak A Fuad Rachmany dalam seminar 'Pajak dan Zakat Relevansinya terhadap Pembangunan dan Kesejahteraan' di Kantor Pusat Ditjen Pajak Jakarta Sabtu (21/5/2011) menyatakan sebagai berikut: "Masih jutaan yang belum bayar pajak, mungkin 50 juta. Berdasar data penyampaian surat pemberitahuan (SPT) Pajak tahun 2010, orang pribadi yang menyampaikan SPT Pajak hanya mencapai sekitar 8,5 juta orang dari total jumlah penduduk Indonesia sekitar 240 juta 
jiwa. Dari jumlah 8,5 juta orang itu pun sebagian merupakan SPT nihil. Penerimaan pajak pada 2010 mencapai Rp600 triliun. Dari jumlah itu, sebesar sekitar Rp300 triliun berasal dari pajak perusahaan atau badan yang jumlahnya 500 badan/perusahaan. Jumlah penerimaan Rp300 triliun itu sebagian besar, yaitu 98 persen berasal dari 200.000 perusahaan. Sementara itu dari 8,5 juta WP orang pribadi, penerimaan pajaknya mencapai Rp200 triliun. Jumlah Rp200 triliun itu sebagian besar atau 98 persen berasal dari 500.000 WP orang pribadi golongan kaya dan menengah. Ini artinya Indonesia saat ini hanya bergantung kepada satu juta WP perusahaan dan orang pribadi. Ini sangat menyedihkan padahal jumlah penduduk 200 juta lebih.

Eksistensi UMKM memang tidak dapat diragukan lagi karena terbukti mampu bertahan dan menjadi roda penggerak ekonomi. Pada tahun 2011 UMKM mampu berandil besar terhadap penerimaan Negara dengan menyumbang 61,9 persen pemasukan produk domestik bruto (PDB) melalui pembayaran pajak, yang diuraikan sebagai berikut : sektor usaha mikro menyumbang 36,28 persen PDB, sektor usaha kecil 10,9 persen, dan sektor usaha menengah 14,7 persen melalui pembayaran pajak. Sementara itu, sektor usaha besar hanya menyumbang 38,1 persen PDB melalui pembayaran pajak (BPS, 2011). Sebagian besar (hampir 99 persen), UMKM di Indonesia adalah usaha mikro di sektor informal dan pada umumnya menggunakan bahan baku lokal dengan pasar lokal. Itulah sebabnya tidak terpengaruh secara langsung oleh krisis global. Laporan World Economic Forum (WEF) 2010 menempatkan pasar Indonesia pada ranking ke-15. Hal ini menunjukkan bahwa Indonesia sebagai pasar yang potensial bagi negara lain. Potensi ini yang belum dimanfaatkan oleh UMKM secara maksimal.

Mengingat adanya Peraturan Pemerintah yang baru yaitu PP Nomor 23 Tahun 2018, kami berupaya mendorong UMKM mitra binaan Pemda Depok agar lebih sadar dan teredukasi mengenai perpajakan maupun pembukuan. Program ini mencakup pemberian pelatihan dan bimbingan terkait materi perpajakan, pembukuan, pencatatan, dalam mendukung program pembinaan UMKM yang merupakan bagian dari strategi otoritas pajak dalam meningkatkan kesadaran dan kepatuhan perpajakan sektor UMKM dan merupakan bagian penting dari perekonomian Indonesia. Namun yang menjadi permasalahan adalah masih lemahnya pengetahuan tentang perpajakan dan pembukuan dari pelaku Usaha Mikro Kecil dan Menengah di Kota Depok, khususnya PP Nomor 23 Tahun 2018 sehingga sangat banyak pelaku UMKM belum melakukan kewajiban perpajakannya sesuai dengan ketentuan perpajakan yang berlaku, serta belum melakukan pembukuan usaha atau pencatatan, sehingga tentu saja hal ini berdampak pada masih belum signifikannya penerimaan pajak dari pelaku UMKM.

Disisi lain, perkembangan UMKM di Indonesia masih sangat lemah yang terkait dengan willingness to innovate (BPPT and KKBP, 2010), UMKM kurang memiliki kemampuan untuk mengakses sumber daya eksternal, jika dibandingkan dengan perusahaan-perusahaan yang berskala besar. Ada beberapa masalah yang umum dihadapi oleh pengusaha kecil mikro dan menengah seperti keterbatasan modal kerja atau modal investasi, kesulitan mendapatkan bahan baku dengan kualitas yang baik dan harga terjangkau, keterbatasan teknologi, sumber daya manusia dengan kualitas yang baik (manajemen dan teknik produksi), informasi pasar, dan kesulitan dalam pemasaran.

Berdasarkan kondisi tersebut, Tim Pengabdian Masyarakat Institut STIAMI ikut berperan dalam memberikan pemahaman dan pengetahuan kepada Wajib Pajak pelaku bisnis UMKM dengan topik "Pelatihan Pembukuan Keuangan Sederhana Dalam Rangka Pelaksanaan Kebijakan Pajak Yang Baru (PP No.23 Tahun 2018) Untuk Pelaku UMKM Naik Kelas di Kota Depok".

\section{B. PELAKSAAAN DAN METODE}

Metode pelaksanaan dari kegiatan pelatihan dan pendampingan mengenai pembukuan dan perpajakan ini dibagi menjadi beberapa metode sebagai berikut:

\section{a. Metode Ceramah}

Penerapan metode ceramah ini disampaikan secara lisan dengan menggunakan alat bantu media yaitu powerpoint untuk memperjelas uraian yang disampaikan, dengan penggunaan metode ini terjadi interaksi antara pemateri dengan peserta, sehingga efektifitas dan efisiensi serta terjadi motivasi dari peserta, apalagi peserta telah menerima bahan atau materi ajar. 


\section{b. Metode Tanya Jawab}

Metode Tanya jawab ini terjadi interaksi dua arah, baik pertanyaan dari pemateri maupun dari peserta. Dengan metode tanya jawab tidak hanya terjadi interaksi dua arah tetapi juga banyak arah. Ketika peserta menanyakan akan muncul beberapa peserta lain yang ikut berinteraksi di dalam pertanyaan tersebut. Dengan demikian tidak hanya pemateri saja yang senantiasa berbicara seperti halnya dengan metode ceramah. melainkan mencakup pertanyaan pertanyaan dan masukan dari peserta lain.

\section{c. Metode Diskusi}

Penggunaan metode diskusi ini sebagai metode penyisipan dari penggunaan metode ceramah dan metode Tanya jawab, khususnya di dalam perhitungan pajak yang dibebankan kepada wajib pajak.

d. Metode Praktek

(Perhitungan pajak dan pembukuan sederhana), metode ini digunakan untuk mengukur sejauh mana tingkat pemahaman terhadap materi yang telah disampaikan oleh pemateri, dengan mengitung masing masing peserta berdasarkan omzet yang diperoleh dalam satu tahun, serta pembukuan sederhana untuk pelaku UMKM.

\section{HASIL DAN PEMBAHASAN}

\section{Pentingnya Pajak Di Indonesia}

Informasi awal yang diberikan adalah mengenai pentingnya pajak di Indonesia, karena sebelum peserta diinformasikan mengenai peraturan terbaru dalam perpajakan mereka diharapkan mengetahui alasan mengapa mereka harus membayar pajak. Banyaknya pelaku bisnis yang tidak mau taat membayar pajak disebabkan oleh minimnya informasi mengenai manfaat pajak. Padahal banyak manfaat yang diterima oleh masyarakat dengan patuh membayar pajak dalam kehidupan sehari-hari. Pajak memiliki peran penting dalam membangun negara khususnya Indonesia, karena sebagian besar pendapatan negara diperoleh dari pembayaran pajak. Pajak di Indonesia berfungsi sebagai:

a. Fungsi Anggaran (budgetair), yaitu pajak dijadikan suatu alat untuk memasukkan dana secara optimal kedalam kas negara berdasarkan peraturan perundang-undangan perpajakan yang berlaku. Dalam hal ini pajak berfungsi membiayai seluruh pengeluaran-pengeluaran yang berkaitan dengan dengan proses kegiatan pemerintahan. Pajak digunakan untuk pembiayaan rutin seperti; belanja pegawai, belanja barang, pemeliharaan dan lainnya. Selisih dari penerimaan negara dikuragi dengan pengeluaran rutin, negara menggunakan uang pajak untuk pembiayaan pembangunan dan sisanya ditabung oleh pemerintah.

b. Fungsi mengatur (regulerend), yaitu pajak digunakan oleh pemerintah untuk mencapai suatu tujuan tertentu dan merupakan pelengkap dari fungsi anggaran sebelumnya. Pemerintah dapat mengatur pertumbuhan ekonomi melalui kebijakan perpajakan. Salah satu contohnya adalah Pemerintah menerapkan tarif pajak yang tinggi untuk Minuman Keras dan Rokok. Gunanya untuk membatasi penggunaan/ konsumsi barang-barang tersebut. Pemerintah juga menetapkan bea masuk yang tinggi kepada produk luar negeri dalam rangka melindungi produksi dalam negeri.

Pajak merupakan sumber pendapatan Negara yang utama. Penggunaan uang yang bersumber dari pajak dimulai dari belanja pegawai sampai dengan pembiayaan proyek pembangunan di Indonesia. Pembangunan fasilitas umum seperti sekolah, rumah sakit, jembatan, jalan-jalan, kantor polisi dan sebagainya dibiayai mengunakan uang yang berasal dari pajak. Uang pajak juga digunakan untuk pembiayaan dalam rangka memberikan rasa aman bagi selurug lapisan masyarakat. Seluruh warga negara dari saat dilahirkan sampai dengan meninggal dunia dapat menikmati fasilitas serta pelayanan dari pemerintah. Semua anggarannya berasal dari pajak.

Dengan pemberian informasi tersebut, peserta yang juga merupakan pelaku bisnis UMKM di wilayah Depok menjadi mengerti betapa pentingnya peranan pajak di Indonesia. Pajak menjadi tulang punggung penggerak perekonomian serta pembiayaan negara. 


\section{Peraturan Perpajakan Terbaru (PP No.23 tahun 2018)}

Di-pertengahan tahun 2013, pemerintah mulai memberikan insentif fiskal kepada pengusahapengusaha UMKM dengan mengeluarkan Peraturan Pemerintah No. 46 Tahun 2013 yang mulai berlaku sejak 1 Juli 2013. Untuk mendorong masyarakat berperan serta dalam kegiatan ekonomi formal, pemerintah memberikan kemudahan dan lebih berkeadilan kepada Wajib Pajak yang memiliki peredaran bruto tertentu untuk jangka waktu tertentu, PP 46/2013 tentang Pajak Penghasilan atas Penghasilan dari Usaha yang Diterima atau Diperoleh Wajib Pajak yang Memiliki Peredaran Bruto Tertentu diganti dengan PP 23/2018 (Pohan, 2017, hal. 335). PP No.23 tahun 2018 Peraturan ini merupakan Peraturan Pemerintah tentang Pajak Penghasilan atas penghasilan dari usaha yang diterima atau diperoleh Wajib Pajak yang memiliki peredaran bruto tertentu yaitu Peredaran Bruto suatu usaha tidak lebih dari 4,8 Milyar dalam satu tahun pajak. Batasan ini secara tidak langsung menargetkan kepada Pelaku Usaha Mikro Kecil dan Menengah (UMKM). Pemerintah memang ingin merangkul sebanyak mungkin pelaku bisnis UMKM untuk masuk kedalam sistem perpajakan.

PP No.23 tahun 2018 mulai efektif sejak 1 Juli 2018, dengan kata lain per tanggal 1 Juli 2018 PP No.46 tahun 2013 sudah tidak berlaku lagi. Peraturan perpajakan ini dibentuk untuk memberikan kemudahan kepada Usaha Mikro Kecil dan Menengah yang memiliki Omzet dalam satu tahun pajak tidak melebihi 4,8 Milyar agar tidak perlu membuat laporan keuangan terlebih dahulu dalam menghitung pajak terutangnya. Pelaku bisnis/usaha yang memenuhi kriteria Peredaran Bruto dalam satu tahun pajak tidak melebihi 4,8 Milyar dapat menghitung pajak terutang dari Omzet yang didapatkan setiap bulan dikalikan dengan tarif pajak yang telah ditentukan.

Terdapat perbedaan tarif yang dikenakan antara peraturan terdahulu yaitu PP No.46 Tahun 2013 dengan PP No.23 Tahun 2018. Jika dalam PP No.46 Tahun 2013 tarif yang dikenakan adalah 1\% dari Omzet, maka di PP No.23 tahun 2018 ini tarif diturunkan menjadi 0,5\% dari Omzet. Ada beberapa ketentuan lain yang perlu diketahui Wajib Pajak dalam hal ini pelaku bisnis UMKM kota Depok mengenai PP No.23 tahun 2018 diantaranya:

\section{Tarif PPh Final 0,5\% bersifat Opsional}

Pembaruan tarif dari peraturan sebelumnya, Pemerintah telah memutuskan untuk memberikan keringanan tarif PPh final yaitu dari $1 \%$ menjadi $0,5 \%$. Jika dahulu semua pengusaha yang memiliki omzet dalam satu tahun pajak mencapai 4,8 Milyar diwajibkan untuk menggunakan PP No.46 tahun 2013, maka dalam PP No.23 tahun 2018 ini pelaku usaha atau wajib pajak dapat memilih untuk menggunakan tarif PPh final 0,5\% atau dapat memilih untuk menggunakan tarif normal yang mengacu pada pasal 17 Undang-undang No.36 Tahun 2008 tentang Pajak Penghasilan.

Wajib Pajak diuntungkan dengan pembaruan peraturan ini karena bagi Wajib Pajak Orang Pribadi maupun Badan yang belum dapat menyelenggarakan pembukuan dengan tertib, penerapan pph final 0,5\% ini dapat memudahkan Wajib Pajak dalam melaksanakan kewajiban perpajakannya. Penghitungan pajaknya menjadi sederhana yaitu $0,5 \%$ dari omzet. Namun yang perlu menjadi pertimbangan adalah Wajib Pajak tetap harus membayar pajak 0,5\% meski dalam keadaan rugi.

Untuk wajib pajak orang pribadi maupun badan yang telah melakukan pembukuan dengan baik, dapat memilih untuk dikenakan Pajak Penghasilan berdasarkan tarif normal yang diatur dalam pasal 17 Undang-undang No.36 tentang Pajak Penghasilan. Wajib Pajak akan terbebas dari pembayaran pajak penghasilan apabila sedang mengalami kerugian.

\section{Pengenaan Tarif PPh Final 0,5\% memiliki Batas Waktu}

Jika dalam PP No.46 tahun 2013 tidak ada batas waktu penggunaan tarif pph final 1\%, dalam peraturan terbaru di PP No.23 tahun 2018 Wajib Pajak memiliki batas waktu penggunaan tarif pph final $0,5 \%$. Batasan waktu yang diberikan oleh pemerintah kepada wajib pajak yang ingin memanfaatkan tarif pph final 0,5\% sebagai berikut:

a. Untuk Wajib Pajak Orang Pribadi maksimal 7 tahun pajak

b. Untuk Wajib Pajak Badan berbentuk CV atau Firma maksimal 4 tahun pajak

c. Untuk Wajib Pajak Badan berbentuk PT maksimal 3 tahun pajak 
Apabila batas waktu sudah terlampaui, maka wajib pajak tidak dapat menggunakan PP No.23 tahun 2018 lagi. Wajib Pajak harus menggunakan tarif normal seperti diatur dalam pasal 17 Undang-undang No. 36 tentang Pajak Penghasilan.

\section{Pihak yang tidak dapat memanfaatkan PPh Final $0,5 \%$}

Dalam penerapan atau pemanfaatan kebijakan PP No.23 tahun 2018, ada pihak-pihak yang tidak dapat memanfaatkan keringanan tarif ini, yaitu:

a. Wajib Pajak Orang Pribadi dengan penghasilan yang diperoleh dari jasa sehubungan dengan pekerjaan bebas (termasuk persekutuan atau firma yang terdiri dari Wajib Pajak Orang Pribadi berkeahlian sejenis seperti Kantor Akuntan, Firma Hukum, dan lain sebagainya.

b. Wajib Pajak dengan penghasilan yang dikecualikan dari objek pajak

c. Wajib Pajak yang penghasilannya telah dikenai PPh yang bersifat final dengan ketentuan peraturan perundang-undangan perpajakan

d. Wajib Pajak dengan penghasilan yang diperoleh di luar negeri yang pajaknya terutang atau telah dibayar diluar negeri

\section{Pembukuan Keuangan Sederhana}

Pembukuan maupun pencatatan keuangan merupakan suatu hal yang penting dilakukan oleh pelaku bisnis usaha. Setiap usaha maupun bisnis berskala besar ataupun kecil perlu membuat pembukuan keuangan meskipun hanya pembukuan secara sederhana. Namun sayangnya, masih banyak pelaku bisnis/usaha yang mengabaikan pentingnya pembukuan terutama pada pengusaha kecil atau pelaku bisnis yang baru. Dalam hal ini kami telah melakukan studi pendahuluan yang menyatakan bahwa masih banyak pelaku bisnis khususnya Usaha Mikro Kecil dan Menengah di kota Depok masih belum memberikan perhatian penuh pada pentingnya memahami pembuatan pembukuan meskipun secara sederhana.

Meskipun beberapa lainnya menyadari akan pentingnya pembukuan, namun mereka tetap enggan untuk membuat pembukuan. Alasannya adalah mereka selaku pengusaha atau pembisnis lebih memberikan perhatian lebih kepada produk dan penjualan atas produk atau jasanya. Padajal selain untuk kepentingan keuangan, pembukuan juga memberikan peran penting untuk mencatat setiap aktivitas bisnis yang berhubungan dengan keuangan termasuk pencatatan transaksi uang masuk dan uang keluar serta pemberian informasi mengenai laba atau rugi. Pembukuan dalam sebuah bisnis juga akan sangat berguna dalam melihat perkembangan bisnis suatu usaha pada periode tertentu.

Fokus terhadap penjualan dan kualitas produk memang merupakan hal yang penting dilakukan untuk kemajuan usaha. Namun ketika usaha yang ditekuni semakin besar dan berkembang, akan semakin banyak transaksi yang terjadi dan harus dihitung aliran dana serta untung dan ruginya. Jika usaha tersebut tidak memiliki pembukuan, bisa saja pemilik usaha akan berfikir bahwa usaha nya sudah mendapatkan omzet yang besar padahal bisa jadi usaha tersebut tidak memiliki dana kas atau profit margin.

Dalam pemberian materi mengenai pembukuan, dapat dimulai dari pembukuan sederhana agar tidak kesulitan dalam memahaminya. Berikut beberapa contoh pembukuan sederhana yang dapat dibuat oleh para pelaku bisnis Usaha Mikro Kecil dan Menengah:

a. Pembukuan Catatan Kas, pembukuan catatan kas merupakan gabungan catatan antara transaksi pengeluaran dan pemasukan. Untuk membuat pembukuan, peserta diminta menuliskan semua pemasukan dan pengeluaran yang terjadi. Pengeluaran merupakan suatu hal penting yang harus diketahui dalam sebuah bisnis. Dengan mengetahui pengeluaran yang terjadi, pelaku bisnis dapat mengetahui jumlah modal usaha yang telah dikeluarkan. Dengan demikian pelaku bisnis dapat merencanakan pengembalian modal usaha, target penjualan dan lain sebagainya dengan mudah. Semua transaksi yang tejadi dalam usaha dicatat mulai dari belanja pembelian bahan baku, kegiatan operasional, administrasi hingga pembayaran gaji karyawan. Jika kita bicara kas, selain ada pengeluaran tentu juga ada pemasukan. Pemasukan juga merupakan hal penting yang harus diperhatikan. Ketika suatu usaha memperoleh pemasukan dari penjualan diharapkan langsung dicatat transaksinya. Dengan melakukan pencatatan secara teratur, pengusaha dapat mengetahui berapa besar 
keuntungan yang diperoleh setiap harinya. Manfaat lain dari penyelenggaraan pembukuan atau pencatatan adalah pengusaha dapat membuat rencana strategis perusahaan apabila suatu saat terjadi hal yang tidak terduga.

b. Pembukuan Persediaan, selain kas, persediaan juga perlu diperhatikan pencatatannya. Karena persediaan memiliki hubungan langsung dengan penjualan. Saat terjadi penjualan, pengusaha harus dapat memastikan bahwa persediaan produk tersedia dan pengusaha juga harus memastikan saat akhir periode persediaan tidak menimbun banyak. Karena jiga persediaan tertimbun banyak, tentu akan menimbulkan kerugian. Pembukuan atau pencatatan persediaan juga dapat digunakan untuk menghindari kecurangan yang dilakukan karyawan. Apalagi jika jumlah persediaan dan transaksi dalam jumlah banyak, maka diharpakan pengusaha dapat membuat kartu persediaan.

c. Pembukuan Investasi Barang, pembukuan inventaris barang merupakan pembukuan yang berisi catatan aset yang dimiliki oleh pengusaha. Untuk membuat pembukuan inventaris barang, pengusaha hanya perlu mencatat setiap barang ataupun aset yang dibeli. Pembukuan inventaris barang ini akan membantu pengusaha untuk menjaga dan mengembalikan aset perusahaan. Manfaat lain dari pembukuan inventaris barang adalah; mempermudah kegiatan mutasi atau penghapusan barang, menjaga atau mencegah barang agar tidak mudah hilang, berntuk pertanggungjawaban dengan memiliki bukti tertulis terhadap pengelolaan barang, mempermudah pengawasan aset, dan mempermudah untuk pengecekan barang.

\section{PENUTUP}

\section{Simpulan}

Acara "Pelatihan Pembukuan Keuangan Sederhana Dalam Rangka Pelaksanaan Kebijakan Pajak Yang Baru (PP Nomor : 23/2018) Untuk Pelaku UMKM Naik Kelas di Kota Depok" telah dilaksanakan pada 29 November 2019 bertempat di New Ayuda Hotel, Bogor dan dihadiri oleh 51 peserta yang merupakan pelaku bisnis Usaha Mikro Kecil dan Menengah (UMKM) kota Depok. Kegiatan berjalan dengan lancar dan mendapatkan respon yang positif dari peserta kegiatan. Peserta kegiatan secara aktif memberikan pertanyaan sesuai dengan materi yang dibahas.

\section{Saran}

Melihat antusiasnya peserta kegiatan, sarankan agar kegiatan ini dapat diseminasikan kepada pelaku UMKM lainnya sehingga pemahaman dan pengetahuan tentang kesadaran dan kepatuhan wajib pajak dapat diketahui masyarakat secara luas. Kegiatan PKM ini diharapkan dapat ditindaklanjuti dengan pendampingan, sampai dengan pelaporan SPT Tahunan.

\section{Ucapan Terima Kasih}

Pada kesempatan ini kami mengucapkan terima kasih kepada semua pihak yang telah membantu pelaksanaan kegiatan pengabdian kepada masyarakat sehingga dapat berjalan dengan baik.

\section{DAFTAR PUSTAKA}

BPS. 2011. Produk Domestik Bruto.

Galeri UKM. 2011. Kriteria Usaha Mikro Kecil dan Menengah.

Kementrian Koperasi dan UKM, (2010), Renstra (Rencana Strategis) Kementrian Koperasi dan UKM

Tahun 2010 - 2014, Jakarta.

Lembaga Intermediary (LI) (BPPT and KKBP, 2010)

Pohan, Chairil Anwar. 2017. Pembahasan Komprehensif Pengantar Perpajakan, Edisi 2. Jakarta:

Mitra Wacana Media

$$
\text { . 2017. Manajemen Perpajakan, Strategi Perencanaan dan }
$$

Bisnis. Edisi Revisi. Jakarta: Gramedia 
PP Nomor 23/2018 tentang Kebijakan Perpajakan UMKM

Bisnis.com 2/5/19 https://ekonomi.bisnis.com/read/20190502/259/917630/masih-minim-penerimaanpajak-dari-sektor-umkm

Pangestika, Widya. 2019. Contoh dan tahapan dalam membuat Pembukuan Sederhana. https://www.jurnal.id/id/blog/pembukuan-sederhana/

Online Pajak. 2018. 7 Point Penting dalam PP 23/2018 Tentang PPh Final 0,5\%. https://www.onlinepajak.com/7-poin-penting-dalam-pp-232018-tentang-pph-final-05

Cermati.com. 2016. Manfaat Pajak Bagi Masyarakat dan Negara. https://www.cermati.com/artikel/manfaat-pajak-bagi-masyarakat-dan-negara 